\title{
SIMILARITIES AND DIFFERENCES IN TEACHING CORPORATE SOCIAL RESPONSIBILITY: EVIDENCE FROM MEXICO AND CANADA
}

\author{
Santiago Gonzalez ${ }^{1}$, Murat Sakir Erogul ${ }^{2}$, Salvador Barragan ${ }^{3}$ \\ ${ }^{1}$ Faculty of Management, Universidad Panamericana, Banaterra Campus, Mexico \\ ${ }^{2 \bowtie}$ Department of Marketing, International Business and Entrepreneurship, Faculty of Business and Economics, Thompson Rivers University, 900 \\ McGill Road, Kamloops BC. V2C 0C8, Canada, +1 778471 8466, merogul@tru.ca \\ ${ }^{3}$ Department of Management, Faculty of Business and Economics, Thompson Rivers, University, Canada
}

\section{Highlights}

- A comparative case study that utilizes curriculum and in-depth interview analysis to illustrate not only the similarities and differences in the CSR programs, but how social responsibility is taught. Our findings indicate that the CS

\section{Abstract}

The need to incorporate and develop Corporate Social Responsibility (CSR) within university programs is necessary for future leaders, managers and entrepreneurs. Within the framework of CSR and stakeholder theory the paper contributes a comparative case study that utilizes curriculum and in-depth interview analysis to illustrate not only the similarities and differences in the CSR programs, but how social responsibility is taught in a Mexican and Canadian University context. The main findings are: the CSR program in Mexico is perceived as a strategic management tool that adds value to the organization and does not pay any special attention to the globalization phenomena. Whereas in Canada, social responsibility is founded on ethics, attention to the different stakeholders in a globalized environment is emphasized and the strategic importance of CSR is widely accepted. The paper provides academics and researcher insight into exploring how universities can further facilitate students as stakeholders in considering social responsibility as important and necessary to ensure CSR sustainability in practice.
\end{abstract}

Article type

\section{Keywords}

Corporate Social Responsibility, Stakeholder theory, case study, education and business, Mexico, Canada

Gonzalez S., Erogul M. S., Barragan S. (2016) "Similarities and Differences in Teaching Corporate Social Responsibility: Evidence from Mexico and Canada", Journal on Efficiency and Responsibility in Education and Science, Vol. 9, No. 3, pp. 70-80, online ISSN 1803-1617, printed ISSN 2336-2375, doi: 10.7160/eriesj.2016.090303.

\section{Introduction}

Bowen (1953) provided the first definition of Corporate Social Responsibility (CSR) as "obligations of businessmen to pursue those policies, to make those decisions, or to follow those lines of action that are desirable in terms of the objectives, and values of our society". In today's globalized world as corporation's gain power and economic relations grow the need for increased commitments and responsibilities arises. This gives way to the need to not only carry out more research on CSR from a stakeholder perspective and develop programs that create understanding and awareness for all parties, but also incorporate CSR curriculum into higher education institution programs. It is becoming increasingly necessary to give greater importance to ethical values and CSR policies in higher education institutions (Gaa and Thorne, 2004; Bampton and Maclagan, 2005; Block and Cwik, 2007) as business schools and faculties of economics and business administration have a stake and responsibility to produce graduates who act in an ethical and responsible way and instigate socially and ethically acceptable operations when they join a company (Pfeffer and Fong, 2004; Cornelius, Wallace and Tassabehji, (2007); Waples et al., 2008). The main rationale behind this argument is that education is a key driver of students' moral and ethical development and that the students of today will become the top managers and policy makers of the future (Armstrong, Ketz, and Owsen (2003). In addition, universities have to consider students as important stakeholders who may have expectations about CSR activities. For instance, Kvasničková Stanislavská, et al. (2014) have noted that current and potential university students have different expectations, as stakeholders, in their involvement in active and passive forms of CSR activities as part of their higher education.
Exposure to CSR in the curriculum has been found to have a significant impact on student perceptions of what should be the ideal linkages between organizational ethical practices and business outcomes (Luthar and Karri, 2005, p.353). Despite this growing interest in CSR in university education, there appears to be a lack of consistency among curricular programs in regards to what is taught. Moreover, this inconsistency may not help students, as future business people, to clearly understand how to implement CSR activities appropriately (Tudev and Lkhagvasuren, 2011). In light of comparatively exploring the current state of CSR education various models and of social responsibility are considered.

Bowen (1953) provided the first definition of CSR which since then has evolved significantly, from good corporate citizenship (Johnson, 1971; Waddock and Boyle, 1995) and ad-hoc philanthropies (Carroll, 1991; Porter and Kramer, 2002; Cochran, 2007), to the stakeholder theory (Freeman, Donaldson and Preston, 1995; Freeman, 1984) and, finally, to a corporate strategy which can be more closely associated with financial performance goals (Lee, 2008). Therefore, it is important that management students take courses on CSR at their undergraduate studies because they will be the future entrepreneurs and managers with a responsibility to achieve orgnaizational success and a better society for everyone. Higher education institutions have been using CSR as part of their competitive strategy (Dahan and Senol, 2012). Moreover, Augier and March (2011), note that the corporate scandals in the USA, along with the normative pressures from the AACSB accreditation body are promoting business schools to teach their 
students a managerial approach that involves CSR. In addition, globalization has inevitably embraced higher education institutions and within this new competitive environment, many higher education institutions have adopted a more businesslike approach in order to compete and survive in the changing education industry (Weymans, 2010; Dahan and Senol, 2012). Both management and faculty need to balance the need to adjust to a changing world while maintaining the organizational identities and the inherent characteristics of higher education (Stensaker, 2007).

In an international survey of 211 scholars with expertise in business ethics, Holland and Albrecht (2013) asked each respondent to identify the three most important issues that business ethics academia will face in the coming decade. The results suggest that the most important issues facing business ethics academia in the future will be the following: curriculum, faculty training, research relevance, and the credibility of the academic field. Consequently, higher education institutions that are adapting a more business-like approach in order to compete and survive in the changing face of industry are discovering the importance of CSR as a reputation and an advantage building strategy (Atakan and Eker, 2007; Stensaker, 2007) which is evident in its aim to embrace responsibility for the company's actions and encourage a positive impact through its activities on the environment, consumers, employees, communities, stakeholders and all other members of the public sphere who may also be considered as stakeholders (Freeman, Harrison and Wicks, 2010).

\section{Corporate Social Responsibility and Stakeholder Theory}

Carroll (1979) suggested that businesses have to fulfill economic, legal, ethical and philanthropic responsibilities in order to address its entire obligations to society. This definition has helped define the four components of social responsibility and broadened the scope of its understanding (Maignan, 2001; Popa, 2010).

The comparative analysis of CSR evolution represented by conceptual models within the literature (Carroll, 1991; Schwartz and Carroll, 2003; Geva, 2008), demonstrates that the same terminology represents different meanings and different approaches to CSR. Its nature, assumptions and limits, methodological tools and the measurement of results are at the same time the cause and effect of how the relations of its elements are understood. It is generally accepted that there are certain responsibilities that give shape to CSR as seen in the three aforementioned CSR models. Firstly, economic responsibilities designate the obligations for businesses to be productive and profitable (Maignan, 2001). Secondly, legal responsibilities refer to the framework of legal requirements which businesses need to meet while practicing economic duties (Carroll, 1979). Thirdly, ethical responsibilities are the defined appropriate behavior by established norms that businesses should follow, and lastly, philanthropic responsibilities reflect the common desire to see businesses get actively involved in the betterment of society (Maignan, 2001).

The CSR concept has transitioned significantly to alternative themes such as business ethics theory, corporate social performance, corporate citizenship and stakeholder theory (Forray and Leigh, 2012, 299). Overall, CSR pays less attention to the interests of the stockholders or owners and comparatively more attention to the public, community and employees (Freeman, Harrison and Wicks, 2010, 60). Whereas stakeholder theory is a grounded attempt to take CSR into practice, by providing balanced attention to all stakeholders' demands. Stakeholder theory was developed as an aid to managers, to face complex realities in a more effective way than other prevalent theories (Freeman, Donaldson and Preston, 1995). Considered as an inclusive theory (Freeman; Harrison and Wicks, 2010), all stakeholders who are a part of the value chain receive a status condition just like the corporate fiduciaries, (Freeman, Harrison and Wicks, 2010). Followers believe that companies have obligations and responsibilities toward all those who are affected by their behaviour (Tricker, 2012; Derry, 2012).

The different CSR models (Carroll, 1991; Schwartz and Carroll, 2003; Geva, 2008) and the stakeholder theory have strong links to one another. Companies are expected not only to fulfill their financial obligations with the stockholders and their legal duties, but also to perform ethically, and to act as good corporate citizens, playing an active philanthropic role.

For the purpose of this paper, the predominance of each stage of the CSR evolution model (Geva, 2008) is identified in CSR programs in two university contexts, a Mexican university, Universidad de Guadalajara (hereafter, UMEX), and a Canadian university, The University of Lethbridge (hereafter, $U C A N)$. Thus, we utilize stakeholder theory to understand what is currently happening in management teaching and CSR in Canada and Mexico. In other words, analyzing CSR curriculum from the perspective of understanding corporations relationships with stakeholders, as corporations are a nexus of a complex web of stakeholder relationships where relationships with specific stakeholder groups are managed rather than with society at large (Jamali, 2008). The following research questions are asked:

\section{What are the differences in the CSR contents of management} programs in Canada and Mexico?

2. What and how is CSR taught in the participating Canadian and Mexican universities?

Within the framework of CSR and stakeholder theory this research explores through a comparative case study how academics at the UMEX and UCAN interpret and utilize the CSR concept. The paper examines the CSR curriculum taught to undergraduate management students and identifies the similarities and differences of the CSR programs to one another. Considering, that the teaching of CSR might have a positive impact on a company's profitability, (Vogel, 2008), it provides incentives to teach it and investigates how to develop it. Exploring how these universities facilitate students as stakeholders in considering social responsibility as important and necessary is significant in regards to CSR sustainability in practice. The objective of this paper is to set comparisons about the contents and practices of CSR teaching to understand to what degree two universities in two different contexts have similarities and differences.

\section{Materials and Methods}

When carrying out research in different geographic regions there is a lack of higher levels of relevant analysis on CSR research that includes countries, economic blocs and geographic regions (Aguinis and Glavas, 2012). For this reason, qualitative research is recommended. This study utilizes an interpretive approach 
(Alvesson and Sköldberg, 2000), where we moved back and forth between theory and empirical material. We use the case study approach to compare the CSR programs at two universities in two different national contexts (Yin, 2003). Therefore, this case study employs collecting in-depth information through semi-structured interviews with academics that teach CSR at UMEX and UCAN. The literature review and curriculum analysis provided the means to identify the differences in the CSR programs contents at both universities.

\section{Contexts and organizational settings}

As part of a broader research project on international comparative education between Canada and Mexico in the context of the NAFTA agreement, this paper presents two case studies on the CSR programs, one from a Mexican university and one form a Canadian university. The selection criteria for these two universities was to be public universities, having a CSR course in business, and their business schools to not be a part of the UN Compact, which allows avoiding the normative pressures (DiMaggio and Powell, 1983) for belonging to a specific accreditation body. In the case of $U M E X$, it was the only public university with a business school that had implemented a CSR course for undergraduate management students in 2013 in Mexico. The Canadian university, UCAN, was selected due to the first author's access to interviewing faculty members thanks to being a visiting professor several times. This university implemented the program "Managing Responsibly in a Global Environment" (MERGE) in 2002.

\section{Mexico and UMEX}

Mexico is an emerging economy with an income per capita of US\$ 10,361.00 (World Bank, 2015). According to the classification of Transparency International (2013), Mexico ranks 106 in honesty out of 177 countries. It also ranks 26 out of 28 countries analyzed in terms of their companies' predisposition to offer bribes when doing business internationally (OECD, 2015). The UN Global Compact Network of Mexico was launched in 2005 and it has 700 participants from businesses and non-business organizations, of which 46 are universities (UN Compact, 2014). It is important to note that in the Mexican context there are both private and public universities.

UMEX is a Mexican public university. It was founded 90 years ago in the state of Jalisco, Mexico. UMEX is the second largest Mexican university. In 2014-2015, UMEX provided higher education to $45 \%$ of Jalisco's population. There are 2,926 full time academics of which $44 \%$ have a doctorate degree. It has 108,425 undergraduate students enrolled and 6,432 at graduate studies.

\section{Canada and UCAN}

Canada is a developed nation with an income per capita of US\$ 50,271.00 (World Bank, 2015). It ranks 9 in honesty out of 177 countries analyzed (Transparency International, 2013). The UN Global Compact Network of Canada was launched in 2013 and it has 159 participants from businesses and non-business organizations, of which 13 are universities (UN Compact, 2014). The majority of universities in Canada are public universities.

$U C A N$ is a Canadian public university. It was founded 50 years ago in the city of Lethbridge in the province of Alberta. UCAN is a comprehensive university that has shown a fast growth in the last years. It has three campuses in the cities of Lethbridge, Calgary and Edmonton. There are more than 500 faculty members of which $94 \%$ have a $\mathrm{PhD}$ degree. It has 7,893 undergraduate students and 560 graduate students.

\section{Data collection}

We collected data in two different stages. In the first stage, we collected documents with the academic programs of CSR from both universities containing the general and specific objectives of the course, the themes and topics covered, along with their description and their duration. The academic authorities and the academics from both universities supplied the information on the students, programmes, materials and methods used to teach the CSR courses analyzed. In the second stage, we conducted semistructured interviews with academics from both universities who teach the CSR course, or who have taught it before, or who participated in the course design. A total of 6 from UMEX and 8 from UCAN were interviewed. We developed an interview guide based on our theoretical framework on the notions of CSR endorsed by the faculty to identify the way they teach it, and understand the links of CSR with specific topics such as globalization, ethics, SMEs, and NGOs, and the expectations on students' research on CSR. While we use the same interview guide for both universities, we made variations if we noted that a CSR topic was or was not covered according to the curriculum review.

The interviews were conducted by the first author who visited both universities. Each interview lasted 1.5 hours on average and they were taped and transcribed. The interviews at UMEX were conducted and analyzed in Spanish. Only the quotes used for comparisons with UCAN were translated into English by the first author and reviewed by the third author. The interviews at UCAN were conducted and analyzed in English.

\section{Data analysis}

The analysis was also conducted in two stages. First, we analyze, and compare, the curriculum of the CSR programs at both universities by: (a) identifying the degree of alignment of topics in the curriculum with the core theories of CSR (i.e. three stages of the CSR and the stakeholder theory). The omissions detected during the program analysis and the differences between CSR programs across universities were also incorporated in our interview guide. Second, once the interviews were transcribed, we coded them in NVIVO going back and forth between our data and: (a) our theoretical framework on core theories of CSR (i.e. three stages of the CSR and the stakeholder theory). The interviews were used to understand the differences between the contents of both CSR programs.

\section{Results}

The CSR course in UMEX is a mandatory in-person course that includes forty theory hours and twenty of practice, making a total of sixty hours per semester. CSR represents six credits for the bachelor in management. Students must have studied principles of management, economy and environment, before having access to the course. From the objectives of the CSR course at UMEX, the purpose of teaching students the 'theoretical and practical components' of CSR is more than a philosophy something that 'can be managed' for the instrumental view of translating it into 'a competitive advantage for organizations and companies that adopt it for practical implementation'. As a strategic tool, they emphasize the use of tools for 'identification of problems, planning, implementation and evaluation' attending to the 'interconnections between organizations and all the interest groups' in the environment. 
The CSR course at UCAN is called Managing Responsible in a Global Environment (MERGE), a core course and a mandatory requirement for the Bachelor Degree of Management. The purpose of teaching students this course is to provide them a philosophical understanding or worldview for 'decision making at the light of the forces of globalization'. This worldview of decision-making is framed as 'ethical decision making' by attending to multiple stakeholders within a 'political, legal, regulatory and social environment'.

\section{Similarities and differences in CSR contents between UMEX and UCAN}

By reviewing the content of the CSR courses at both universities, we identified similarities and differences (see Table 1 in Appendix). In both universities the content of the program provides assistance as a teaching guide for the faculty to teach the course. However, faculty members may use their academic freedom to provide a particular focus to any topic or assign more weight to some than others. We also conduct interviews with faculty members from both academic institutions to provide more depth and nuance to the comparison of content.

\section{Similarities in course content}

In both programs the notion on CSR is introduced as a general framework emphasizing the importance of "corporate social responsibility" (UMEX: unit 1; UCAN: units $1.1 \& 1.2$ ) not only for businesses (or organization) but also for society, including its economic development (UMEX: units 2.1, 2.2 \& 2.3; UCAN: 2.1). In addition to this general emphasis, CSR represents opportunities for the creation of value for different "stakeholders".

In both programs "strategic" and "social" aspects of CSR are covered (UCAN: unit 11; UMEX: units 1.9, 2.2 \& 2.5). These two aspects reflect the foundational themes in strategic management of the stakeholder approach (Freeman, 1984). We identify that both programs underlie the importance of stakeholders for the organization. The UMEX (units 3.2, $3.3 \&$ \& 3.4) calls them "interest groups" while the UCAN (units 7.3, 8.1, 8.2, 9.1 \& 9.2) uses the common label of "stakeholders". The content in both cases makes reference to the strategic "management" of them. This focus on managing strategically the stakeholders is aligned with Freeman's (1984) view on CSR companies that deal with a variety of stakeholders or interest groups. It also resembles the view of "good management theorist" who point to the link between adequate attention to stakeholder groups and "corporate social performance" (Waddock and Graves, 1997, p.306). Moreover, it has been noted that the adoption of CSR may help managers to deal a complex reality to achieve organizational effectiveness (Freeman, Harrison and Wicks, 2010), such as dealing with different stakeholders. However, the UCAN (unit 7.3) points out particular distinctions of the different types of stakeholders by noting the importance of consumers, as stakeholders, while the UMEX (unit 2.4) refers to stakeholders in general, pointing to the stakeholders "related" to the organization.

Another topic covered in both universities is "business ethics" (UMEX: unit 1.7; UCAN: unit 4.2) underlying its importance in business and in organizations. In both cases ethics is mentioned as part of pursuing good "corporate governance" (UMEX: unit 1.7; UCAN: unit 5.2).

The topic of "environment" and "sustainability" are both within the course contents (UMEX: unit 2.3; UCAN: units 8.1 \& 8.2). There is a subtle difference in relation to UCAN's program that makes an explicit link to stakeholders. On the other hand, UMEX does not mention the stakeholders when talking about the environment and sustainability (units $2.4 \& 3.3$ ). From this, we can argue that UCAN has more specific themes when referring to the types of stakeholders and their link to specific topics of CSR, while UMEX treats the "interest groups" in a more general way in the program content. The "owners" as stakeholders (UCAN: unit 9.1) have social responsibility, or as mentioned before, they have to be in charge of developing good "corporate governance" (UMEX: unit 1.9) as mentioned in both programs.

Finally, the topic of "socially responsible investments" (UCAN: unit 12.1) partially relates to the topic of "maximization of the partner/stockholder values vs. maximization of society's value" at UMEX (unit 2.5). Notwithstanding, the latter is presented as a dichotomy between benefiting the investor vs. benefiting the society. Therefore, there might be a difference in focus on this theme.

\section{Differences in course content}

While both programs have equal weight in hours and credits, the CSR course at UMEX has four thematic units and the program at UCAN includes twelve. It was also detected that at UMEX, the four units of the CSR course are displayed in twenty-one subjects, while at the UCAN the program has twelve units displayed in twenty subjects.

The introductory chapter of UMEX has a subtopic that make an explicit focus on and the "objective view of CSR" and the "subjective-corporate reputation" (UMEX: unit 1.4). This topic does not appear on UCAN's program. This topic is in line with what Orlitzky, Schmidt and Rynes (2003) contend in regards to the link between CSR and corporate reputation and their impact on financial performance.

UCAN has a complete unit on "Globalization" (UCAN: unit 10), while UMEX does not include a general topic on globalization but two specific subtopics on "internationally approved initiatives in Europe and Latin America" (unit 1.3) and "international initiatives on CSR" (unit 3.1). The omission of "globalization" by UMEX is explored in the analysis of interviews.

Unit 4 in UMEX considers the specific topics of NGOs (unit 4.1) and SMEs (unit 4.2), which are absent in the UCAN program. These are important topics in CSR. In particular, NGOs may voice the needs of secondary and tertiary stakeholders (Wexler 2000). Moreover, many organizations engage in a minimalist CSR attending to the primary stakeholders (e.g. stockholders, employees, clients, suppliers) who are located at the core of the companies' market and ignoring the secondary (e.g. local communities and social activists) and tertiary (e.g. environment, wildlife, future generations) stakeholders (Ibid).

UCAN offers a variety of subtopics on "Ethics" in Units 4, 5 \& 6. In particular, the subtopic of "Ethics in business schools" (UCAN: unit 4.1) is not present at UMEX. We also find that other subtopics on "ethics", in Unit 5 at UCAN are also not present at UMEX, such as "Personal ethics" (unit 5.1) and "Ethics and technology" (unit 5.3). However, both programs do match in reference to the topic of "Business ethics" (UCAN: units 4.2 
\& 5.2; UMEX: unit 1.7), resonating with Freeman, Harrison and Wicks (2007), on their view that the majority of business decisions have an ethical component. UCAN also offers "Ethics in global business" (unit 6.1) which is absent at UMEX. The UCAN program has more emphasis on ethics than UMEX in different areas through five subtopics across three different units. This difference is explored in the interview analysis with UMEX's faculty.

The program at UCAN includes the topics of "business and government" (unit 7.1) and "business ideology in Canada" (unit 7.3). These topics are not offered by UMEX. It is interesting to note that UMEX is not explicitly offering these subtopics to create student's awareness in regards to the corruption levels in Mexico that may be linked to "government and business", and/or "business ideology". Drawing on Logsdon and Wood's (2002) notion of CSR as social control on business, and Porter's and Kramer's (2006) suggestion that businesses should adopt a social perspective into their business strategies, we argue that a social business ideology may be an important omission at UMEX.

As mentioned previously, both universities include the topic of stakeholders within their program. This is an important component of CSR noted by Freeman's (1984) stakeholder theory. Nevertheless, UMEX mentions the stakeholders in the program content in a more general way by referring to them as "interest groups" (units $3.3 \& 3.4$ ), while UCAN presents specific stakeholders from the "community" or from the "environment" (units $8.1 \& 8.2$ ). In relation to CSR theory, Freeman (2010) contends that organizations have to be inclusive of all stakeholders rather than separating the ones that count and the ones that do not. However, he also clarifies that while all of them have the right to be heard, not all of them are equally important at least all of the time for the organization. Therefore, the role of faculty in both universities is important to point out the inclusiveness of all the stakeholders and the relevance of some of them in particular times for the organization.

Continuing with the importance of stakeholders in both programs, we find that both universities have a topic on managing stakeholders (UCAN: unit 9.2; UMEX: unit 3). The only apparent difference is that UCAN has a "simulation of stakeholder's management" which positions students to roleplay possible scenarios.

UCAN has a specific topic on "socially responsible investments" (UCAN: unit 12.1) that partially relates to the topic of "maximization of the partner/stockholder values vs. maximization of society's value" at UMEX (unit 2.5). There is clearly a difference in both programs because UCAN is intending to create students' awareness investing in socially responsible organizations though the stock exchange. In fact, they also offer the subtopic "Corporate Knights' a guide for socially responsible investments" (UCAN: unit 12.2). This guide may help students realize that external parties have the responsibility of monitoring organizations' (lack of) ethical behaviour. On the other hand, UMEX approaches this subtopic from the point of view of the equity partner in the organization who may sacrifice the maximization of her investment return for the purpose of maximizing the society's value. The stand point of UCAN is more aligned with Long and Rao's (1995) argument, based on some empirical evidence, that unethical behaviour in organizations have a negative impact on return on investments.

Finally, we note that UCAN explicitly expects and facilitates students to engage in "research work" related to CSR in organizations. Students compare two companies' websites, from a specific industry, in order to identify the CSR activities reported on the companies' websites. In addition, they identify to what extent these activities are industry related as a norm. The UMEX program on the other hand does not explicitly require research work.

In summary we have presented the similarities and differences between the CSR content in both programs. Now we present our analysis of the interviews with faculty members from both academic institutions to untangle some of these variances.

\section{Interviews at UMEX}

\section{Notion of CSR}

We found a common theme among the interviewed faculty who consider CSR as a responsibility and a commitment that organizations have. Therefore, they have to teach students this notion of CSR: "This is a very important course in our curricula because organizations have an important impact on the external environment" (FMEX\#2). In this view, the responsibility that organizations have is linked to a variety of stakeholders, as suggested by faculty 4: "Companies have to consider their responsibility towards both the internal clients, employees, and the external clients, including the external social environment" (FMEX\#4).

The notion of CSR is also considered as a specific way of managing organizations, comments faculty 3 : "it is a form of managing companies, departing from a responsibility towards society" (FMEX\#3). Then, students learn that organizations can adopt CSR as acquiring a strategic tool that offers specific advantages for the organization as explained by faculty members 5 and 6 :

I teach my students that if you have two companies in the same industry, what makes them different or provides with a competitive advantage? Being socially responsible can provide some level of competitive advantage (FMEX\#5)

In our course we teach students that companies that focus on social responsibility have an advantage over those that ignore that aspect. Then, they can use it as a strategic tool not only for decision making but also with their clients (FMEX\#6)

\section{Business ethics and globalization}

The CSR program at UMEX does not make a strong emphasis on business ethics. It is covered in just one topic on the curricula because it is already covered in a previous course. Faculty 1 explains:

We have a previous course called "professional ethics and social values". In that course, we spend a semester discussing ethics in a deeper way (FMEX\#1).

The program content does not mention explicitly the topic of globalization. It is left at the discretion of the faculty member in charge of teaching the course. Faculty 2 claims that: 
It is not a topic per se; however, we discuss some of the themes with a global perspective (FMEX\#2).

Faculty 4 also mentions the inward rather than the outward aspect of globalization in business. She says:

Yes, globalization is not a topic in our program but we certainly touch upon it. Probably, we discuss it on how global business are coming to Mexico and the impact they have on our country, rather than Mexican companies going abroad (FMEX\#4).

Not all faculty members discuss the pros and cons of globalization, but faculty 5 makes this emphasis in his class: "We talk in class about the pros and cons of globalization. Specifically, we discuss how globalization may create inequalities" (FMEX\#5).

\section{Specific topics (SMEs, NGOs, CSR Investment)}

In this section of the interviews, we focus on three special topics of CSR: SMEs, NGOs, CSR Investment. The topic of SMEs is relevant within the Mexican context because they represent the majority of the businesses: "In Mexico we do not only have SMEs but also micro-SMEs who provide employment or selfemployment to the majority of the population. Accordingly, this is an important topic for CSR" (FMEX\#3). In a similar vein, faculty 6 notes the importance of SMEs in Mexico and CSR: "SMEs are very important in Mexico, and we have to bring the applicability of the topics of CSR to these type of companies. SMEs can also benefit strategically by adopting CSR" (FMEX\#6). The second special topic is the NGOs that is very important not only in the curricula but also in the comments made by the interviewed faculty. Here we show two extracts from interviews highlighting its importance: "NGOs are very important for the analysis of stakeholders because they can have an important impact on organizations" (FMEX\#2). Faculty 1 also comments: "The relationship between companies and NGOS is like a symbiosis. They affect each other; therefore, companies have to take this into consideration when making decisions or reacting to NGOs' demands" (FMEX\#1).

The topic of CSR investment is neither mentioned in the program nor discussed by the faculty due to the claim of not having knowledgeable faculty members who at that time were in charge of both developing the course and teaching it. Faculty 3 refers to the creation of the CSR program: "When the program was designed, we did not bring that topic because some faculty did not consider it important or because the lack of knowledge on it" (FMEX\#3). Even during subsequent revisions to the program, the CSR investment was not considered, as explained by faculty 5: "In our discussion to make adjustment and improvement to the program, the topic of investing with a social responsible attitude did not emerge as needed. Probably, we do not know much about it or it just does not apply to the Mexican context" (FMEX\#5).

\section{Student research}

The interviewed faculty recognized that in the curricula it is not a primary objective for students to do research on the CSR topic. Some faculty who do research may ask students to investigate some topics and may only ask students to get involved in some form of practical research on what companies are doing in terms of CSR: "Research is not a priority for our faculty, then, just the ones who have a $\mathrm{PhD}$ degree may be more inclined to engage students in research" (FMEX\#2). Faculty 6 explains what he has done in terms of research but he asserts that he might be one of the few doing this:

My students have to identify a few companies and what they do with their stakeholders. They have to visit a company and report whether the company is adopting CSR practices or not. If they are, then students have to study what they did and how they did it. If not, they have to suggest possibilities in the context of the company and see the reactions from the management (FMEX\#6)

\section{Interviews at UCAN}

\section{Notion of CSR}

The faculty at UCAN considers CSR from the perspective of the "stakeholder management approach" as a "balanced but complex equation", where they try to teach students that: "they have to consider economic benefits for stockholders, while considering societal needs as a whole, represented by a variety of stakeholders" (FCAN\#1).

Another faculty member (FCAN\#2) recalls when they reviewed the curricula of the business program, and the idea of preparing students to "respond to a variety of stakeholders" to stop this trend of negative reputation of solely being concerned with "monetary benefits for the organization". Back then, he recalls, they proposed to have a core course on CSR, within the business program, with the purpose of making students aware of the different stakeholders that companies have a responsibility with. At the same time, faculty 4 comments that "managing stakeholders" is a complex task because "organizations have limited resources", therefore, managers need to "establish priorities" in terms of "stakeholders' needs and claims" (FCAN\#4). Similarly, faculty 6 mentions that "regardless of the economic impact" for the company, managers need to "assess the pros and cons" of attending to stakeholder needs and claims in terms of the potential impact on the business (FCAN\#6).

\section{Business ethics and globalization}

The topic of business ethics is spread out in four subtopics as it is considered relevant for all interviewed faculty. Interviewee 3 asserts how "personal ethics is the foundation of ethics in business and CSR" (FCAN\#3). Faculty 5 also supports the importance of ethics in the CSR program by adding: "ethics in organizations is the sum of all the individual's ethical behavior within the organization" and for that reason, he says "four topics on ethics is not much" (FCAN\#5). Finally, a faculty member links ethics with stakeholders when teaching students that "there are conflicting points of view, and tensions, when making business decisions that affect more than one stakeholder" (FCAN\#7).

Globalization is a core theme in the UCAN's CSR program as stated by one faculty: "students need to be capable of linking ethical issues in the context of globalization, even if the company is domestically located" (FCAN\#5). Similar to this view is commented by another interviewee who asserts that "we live in a globalized world in which organizations are competing. Then, many of our students will face this interconnectedness in global operations, and we need to show them the potential ethical problems they will encounter" (FCAN\#2). Faculty at UCAN considers that students need to reflect with a global mindset when considering ethical implications. 


\section{Specific topics (SMEs, NGOs, CSR Investment)}

SMEs are not covered at UCAN. Faculty seem to center their focus, analysis and examples on big corporation. Faculty 8 attributes this omission to "the lack of research on SMEs and CSR" (FCAN \#8). Similarly, faculty 4 states that "the media and the case studies we have access to present the big corporations because there is more information on them and usually they are an easy target for many stakeholders" (FCAN\#4). However, they also comment that size should not be an issue for considering CSR activities, as mentioned by faculty 1: "we should cover SMEs and big corporations when showing examples to our students, because at the end of the day, all companies have to behave ethically" (FCAN \#1).

The topic of NGOs at UCAN is not considered a special topic because it is woven into the discussion of managing stakeholders. Some of the faculty cover NGOs as part of the stakeholder management approach but it is up to the instructor: "each instructor makes more or less emphasis on NGOs, but certainly, we discuss it when we talk about the variety of stakeholders" (FCAN\#7). Similarly, faculty member 2 comments: "I won't say that NGOs are a core topic in our curricula but it is an important topic to touch in our course" (FCAN\#2).

In regards to CSR Investment, faculty at UCAN emphasize the importance of paying attention to the CSR monitoring conducted by third parties such as the "Corporate Knights":

The CSR investment guides create awareness in society, and also for our students, of which companies are following some level of standards for ethical behavior. These students in a point in time will be making decisions on investing and/or making decisions in organizations to appear in those rankings (FCAN\#6)

Another interviewee, faculty 5, comments that:

These types of CSR rankings create pressures for companies to respond to societal interest. At the same time, these pressures can drive more performance on companies that are more socially responsible because more investors decide to put their money in them" (FCAN\#5).

Finally, UCAN is also under certain pressure to show students the rankings of the Corporate Knights every year as stated by faculty 3: "students participate in CSR and ethics case competitions, and we have to present reports of what we are doing in terms of CSR, including the adoption of these rankings" (FCAN\#3).

\section{Student research}

At UCAN students have to engage in a research project regardless of who the instructor is. The reasons for this, as pointed out by one faculty member is that "students need to go beyond the textbook and collect empirical evidence by themselves to be aware of what is happening out there" (FCAN\#7). Similar to this reason is the one expressed by faculty 4 who states that "students will find through their research project that companies incorporate CSR activities in different degrees. None of the companies are perfect, but the important part is that they do at least some form of CSR" (FCAN\#4).

\section{Discussion}

The aim of this paper was to compare the content of the curricula and the way Corporate Social Responsibility is taught at two different public universities located in two different contexts in North America: Canada and Mexico.

Previous studies have noted the need to understand what type of business ethics and CSR curriculum have to be taught in business schools and how it has to be conducted to provide students with a solid background to respond to societal concerns (e.g. Gaa and Thorne, 2004; Bampton and Maclagan, 2005; Block and Cwik, 2007). This study served to provide an in-depth case study analysis of two universities located in two different contexts and cultures. The purpose of the comparison allows us to establish the similarities in program content that may reveal the normative standards in North America, while the differences provide potential learning lessons from each setting.

In relation to the first research question, what are the differences in the CSR contents of management programs in Canada and Mexico, we found subtle differences in their views. Firstly, the CSR course at UCAN is closer to the stakeholder theory. Secondly, while UCAN seems to place greater emphasis on different subtopics on ethics compared to UMEX, the latter has a previous course on ethics. Yet, both universities emphasize ethics for business students. Thirdly, the alliance between the non-governmental organizations and businesses, appears to be a more relevant topic for UMEX. Finally, research work conducted by students is more structured and considered an integral part of the program at UCAN compared to UMEX.

In respect to our second research question, what and how is CSR taught in the participating Canadian and Mexican universities, we summarize that in both universities, the CSR course is mandatory with the purpose to create awareness and to provide students with the foundations on theories of CSR and tools to engage in creating a sustainable economy, where both business and society benefit. In terms of program content, both universities include the core topics of CSR matching in more or less degree the three stages of CSR (Geva, 2008). They also consider the importance of stakeholders as strategic partners for the organization, and an ethical responsibility for organizations as described in the stakeholder management theory (Freeman et al., 2010). In UMEX, the teaching of CSR is perceived as a strategic management tool that adds value to the organization and does not pay any special attention to the globalization phenomena. Whereas in UCAN, social responsibility is founded on ethics, attention to the different stakeholders in a globalized environment is emphasized in how CSR is taught, and the strategic importance of CSR is facilitated within the curriculum. Both programs take into consideration the role of entrepreneurs and the responsibility they have towards the different stakeholders in their teachings, and the importance of CSR as a management strategy; however, this notion is more heavily emphasized in the UMEX program.

The main challenges in CSR has been identified as curriculum, faculty training, research relevance, and credibility of academic field plus the reputation and building strategy in Business oriented studies (Maignan, 2001; Popa, 2010). Both universities are taking positive steps towards complying with these challenges. However, each university can learn from the other, comparatively, we highlight that UCAN may consider 
adding small and medium size companies, alliance and relations between business and NGO's with more attention to NGO's in its curriculum. On the other hand, UMEX in comparison to UCAN, may consider adding globalization and CSR, giving more emphasis to Ethics than UMEX and the issues of socially responsible investors and research. These additions will provide further alignment to PRME and the credibility and reputation to each institution. Both Institutions may take further steps in training their faculty and lastly, UMEX lack of research and research training may be overcome through stronger alignments to PRME and a progression towards AACSB membership.

This study as any other has its limitations and as a comparative case study it only provides us the current state of what is taking place in CSR teaching in two universities, one in Canada and one in Mexico. None of these business schools are AACSB accredited, therefore, we may find more similarities in those that have to "appear" more standardized in relation to normative prescriptions (Meyer and Rowan, 1991) of best practices in CSR. More research is needed to draw out prescriptive models to help practice and facilitate the development of theory. On the other hand, future research can also give voice to student's expectations and perceptions on the CSR activities offered by the universities in addition to the traditional curricula (Kvasničková Stanislavská, et al., 2014).

\section{Conclusions}

Our paper contributes to the literature of teaching business ethics and corporate social responsibility in business schools. In particular, we set the study in two contexts in North America highly influenced by the teaching practices in the USA: Canada and Mexico. We center our attention on some of the most important issues that business schools and academics in business ethics and corporate social responsibility will face in the next decade: curriculum and the way CSR has to be taught (Holland and Albrecht, 2013). By studying these two universities we were able to uncover similarities and differences in curricula. In addition, we conducted post-hoc interviews with faculty members in order to understand some of the differences between these two CSR programs. Finally, we draw some learning lessons from each of universities that provide us a window to study in more depth the how and why to teach specific aspects of CSR.

\section{References}

Aguinis, H. and Glavas, A. (2012) 'What we know and don't know About Corporate Social Responsibility: A Review and Research Agenda', Journal of Management, Vol. 4, No. 38. http://dx.doi.org/10.1177/0149206311436079

Alvesson, M. and Sköldberg, K. 2000. Reflexive Methodology. London: Sage.

Armstrong M.B., Ketz, J.E. \& Owsen, D. (2003) 'Ethics education in accounting: moving toward ethical motivation and ethical behaviour', Journal of Accounting Education, Vol. 21, No. 1, pp.1-16. http://dx.doi.org/10.1016/s07485751(02)00017-9

Atakan, M.G.S. and Eker, T. (2007) 'Corporate identity of a socially responsible university: a case from the Turkish higher education sector', Journal of Business Ethics, Vol. 76, pp. 5568. http://dx.doi.org/10.1007/s10551-006-9274-3

Augier, M. and March, J. (2011) The Roots, Rituals and Rhetorics of Change, North American Business Schools After the Second World War. Stanford Business Books, Stanford University Press. http://dx.doi.org/10.3917/mana.145.0372

Bampton, R. and Maclagan, P. (2005) 'Why teach ethics to accounting students? A response to the skeptics', Business Ethics: A European Review, Vol. 14, No. 3, pp.290-300. http:// dx.doi.org/10.1111/j.1467-8608.2005.00410.x

Block, W. and Cwik, P.F. (2007) 'Teaching business ethics: a classificationist approach', Business Ethics: A European Review, Vol. 16, No. 2, pp.98-106. http://dx.doi.org/10.1111/ j.1467-8608.2007.00480.x

Bowen, H.R. (1953) Social Responsibilities of the Businessman, Harper and Row, New York.

Carroll, A.B. (1979) 'A Three-Dimensional Conceptual Model of Corporate Performance', Academy of Management Review, Vol. 4, pp.497-505. http://dx.doi.org/10.5465/amr.1979.4498296 Carroll, A.B. (1991) 'The Pyramid of Corporate Social Responsibility: toward the Moral Management of Organizational Stakeholders', Journal of Business Horizons, pp.39-48. http:// dx.doi.org/10.1016/0007-6813(91)90005-g

Cochran, P.L. (2007) 'The evolution of corporate social responsibility', Business Horizons, Vol. 50, No. 6, pp.449-454. http://dx.doi.org/10.1016/j.bushor.2007.06.004

Cornelius, N., Wallace, J. and Tassabehji, R. (2007) 'An analysis of corporate social responsibility, corporate identity and ethics teaching in business schools', Journal of Business Ethics, Vol. 76, No. 1, pp.117-135. http://dx.doi.org/10.1007/s10551-0069271-6

Dahan, G.S. and Senol, I. (2012) 'Corporate social responsibility in higher education institutions: Istanbul Bilgi University case', American International Journal of Contemporary Research, Vol. 2, No. 3, pp.95-103.

Derry, R. (2012) 'Reclaiming Marginalized Stakeholders', Journal of Business Ethics, Vol. 111, No. 2, pp. 253-264. http:// dx.doi.org/10.1007/s10551-012-1205-x

Dimaggio, P.J. and Powell, W. (1983) 'The iron cage revisited: institutional isomorphism and collective rationality in organizational fields', American Sociological Review, Vol. 48, pp. 147-60. http://dx.doi.org/10.2307/2095101

Donaldson, T. and Preston, L.E. (1995) 'The stakeholder theory of the corporation: concepts, evidence, and implications', The Academy of Management Review, Vol. 20, No. 1, pp.65-91. http://dx.doi.org/10.5465/amr.1995.9503271992

Forray, J. M., and Leigh, J. S.A. (2012) ‘A primer on the Principles of Responsible Management Education: Intellectual roots and waves of change', Journal of Management Education, Vol, 36, pp.295-309. http://dx.doi.org/10.1177/1052562911433031

Freeman, E.R. (1984) Strategic Management: A stakeholder approach. Pitman Publishing, Business and Public Policy Series. Cambridge University Press. New York.

Freeman, E.R. (1994) 'The Politics of Stakeholder Theory: Some Future Directions', Business Ethics Quarterly, Vol. 4, No. 4, pp.409-422. http://dx.doi.org/10.2307/3857340

Freeman, E.R., Donaldson, T. and Preston, L.E. (1995) 'The Stakeholder Theory of the Corporation: Concepts, Evidence, and Implications. The Academy of Management Review, Vol. 20, No. 1, pp.65-91. http://dx.doi.org/10.5465/amr.1995.9503271992

Freeman E., Harrison J., Wicks A. (2007) 'Managing for Stakeholders: Survival, Reputation and Success', Yale University Press.

Freeman, E.R., Harrison, J.S. and Wicks, A.C. (2010) Stakeholder Theory, the State of the Art. Cambridge University Press. Cambridge. http://dx.doi.org/10.1080/19416520.2010.49 5581

Gaa, J.C. and Thorne, L. (2004) 'An introduction to the special issue on professionalism and ethics in accounting education. Issues in Accounting Education, Vol. 19, No. 1, pp.1-6.

Geva, A. (2008) 'Three Models of Corporate Social 
Responsibility: Interrelationships Between Theory, Research and Practice', Business and Society Review, Vol. 113, No. 1, pp.1-41. http://dx.doi.org/10.1111/j.1467-8594.2008.00311.x

Holland, D. And Albrecht, C. (2013) 'The worldwide academic field of business ethics: scholar's perceptions of the most important issues', Journal of Business Ethics, Vol. 117, pp. 777788. http://dx.doi.org/10.1007/s10551-013-1718-y

Jamali, D. (2008) 'A stakeholder approach to corporate social responsibility: a fresh prespective into theory and practice', Journal of Business Ethics, Vol. 82, pp.213-231. http://dx.doi. org/10.1007/s10551-007-9572-4

Johnson, H.L. (1971) Business in Contemporary Society: Framework and Issues, Wadsworth, Belmont, CA.

Kvasničková Stanislavská, L., Kvasnička R., Kuralová K., and Margarisová K. (2014) 'Social Responsibility of Higher Educational Institutions - the Comparison of the View of Students and Potential Students', Journal on Efficiency and Responsibility in Education and Science, Vol. 7, No. 3-4, pp. 95-99. http://dx.doi.org/10.7160/eriesj.2014.070308

Lee, M-D.P. (2008) 'A review of the theories of corporate social responsibility: its evolutionary path and the road ahead', International Journal of Management Reviews, Vol. 10, No. 1, pp.53-73. http://dx.doi.org/10.1111/j.1468-2370.2007.00226.x Logsdon, J. and Wood, D. (2002) 'Business citizenship: From domestic to global level of analysis', Business Ethics Quarterly, Vol. 12, No. 2, pp.155-187. http://dx.doi.org/10.2307/3857809 Long, D.M. and Rao, S. (1995) 'The wealth effects of unethical behavior', Journal of Economics and Finance, Vol. 19, No. 2, pp. 65-73. http://dx.doi.org/10.1007/bf02920510

Luthar, H.K. and Karri, R. (2005) 'Exposure to ethics education and the perception of linkage between organizational ethical behavior and business outcomes', Journal of Business Ethics, Vol. 61, pp.353-368. http://dx.doi.org/10.1007/s10551-0051548-7

Maignan, I. (2001) 'Consumer's Perceptions of Corporate Social Responibilities: A Cross-Cultural Comparison', Journal of Business Ethics, Vol. 30, pp.57-72.

OECD, (2015) OECD's document with regards to bribes, [online] http://www.oecd.org (accessed 22 July 2015).

Orlitsky, M., Schmidt, F. L. and Rynes, S. L. (2003) 'Corporate Social and Financial Performance: A Meta-Analysis', Organization Studies, Vol. 24, No. 3, pp. 403-441. http://dx.doi. org/10.1177/0170840603024003910

Pfeffer, J. and Fong, C.T. (2004) 'The business school "business": some lessons from the US experience', Journal of Management Studies, Vol. 41, No. 8, pp.1501-1520. http:// dx.doi.org/10.1111/j.1467-6486.2004.00484.x

Popa, O. (2010) 'Organizational Social Responsibility - State of The Art. Revista Tinerilor Economisti', The Young Economists Journal, Vol. 1, No. 15S, pp.59-68.

Porter, M.E. and Kramer, M. (2002) 'The competitive advantage of corporate philanthropy', Harvard Business Review, Vol. 80, No. 12, pp.57-68.

Schwartz, M.S. and Carroll, A.B. (2003) 'Corporate Social Responsibility: A Three Domain Approach', Business Ethics Quarterly, Vol. 13, No. 4, pp.503-530. http://dx.doi.org/10.5840/ beq200313435

Stensaker, B. (2007) 'The relationship between branding and organizational change', Higher Education Management and Policy, Vol. 19, No. 1, pp.13-29. http://dx.doi.org/10.1787/ hemp-v19-art1-en

Transparency International, (2013) Corruption by Country / Territory, Canada and Mexico [online] http://www.
transparency.org/country\#CAN and http://www.transparency. org/country\#MEX (accessed 24 May 2014).

Tricker, RI. (2012) 'The Cultural Dependence of Corporate Governance', Keeping Good Companies, Vol. 64, No. 1, pp.2731.

UN Global Compact. (2014) What Is UN Global Compact. [online] https:/www.unglobalcompact.org/what-is-gc/mission/ principles (accessed 3 July 2014).

Tudev, O., Lkhagvasuren, E. (2011) 'The Implementation of Corporate Social Responsibility in Mongolian Business Sector', Journal on Efficiency and Responsibility in Education and Science, Vol. 4, No. 2, pp. 89-96, ISSN 1803-1617.

Vogel, D. (2008) The Market for Virtue, The Potential and Limits of Corporate Social Responsibility, Brookings Institution Press. USA. http://dx.doi.org/10.1002/bse.535

Waddock, S.A. and Boyle, M. (1995) 'The dynamics of change in corporate community relations', California Management Review, Vol. 37, No. 4, pp.125-141. http://dx.doi. org/10.2307/41165814

Waddock S. and Graves S. (1997) 'The corporate social performance - financial performance link', Strategic Management Journal. Vol. 18, No. 4: 303-319.

Waples, E.P., Antes, A.L., Murphy, S.T., Connelly, S. and Mumford, M.D. (2008) 'A meta-analytic investigation of business ethics instruction', Journal of Business Ethics, Vol. 87, No. 1, pp.133-151. http://dx.doi.org/10.1007/s10551-0089875-0

Wexler Mark N. (2000) Confronting Moral Worlds: Understanding Business Ethics, Corporate Social Responsibility, Scarborough: Prentice Hall: 75-111.

Weymans, W. (2010) 'Democracy, knowledge and critique: rethinking European universities beyond tradition and the market', London Review of Education, Vol. 8, No. 2, pp.117126. http://dx.doi.org/10.1080/14748460.2010.487329

World Bank Group (2015) World Bank Group. [online] http:// www.worldbank.org/en/country/canada http://www.worldbank. org/en/country/mexico (accessed 25 March 2015).

Yin, R. K. (2003) Case Study Research: Design and Methods (Third ed. Vol. 5), Thousand Oaks, CA: Sage Publications Inc. 


\section{Appendix}

Table 1. CSR Content at UMEX

\begin{tabular}{|l|}
\hline \multicolumn{1}{|c|}{ UMEX } \\
\hline Unit 1: Introduction to Corporate Social Responsibility. \\
1.1. Origin and main concepts \\
1.2. Positive and negative delimitation of CSR. What it is and \\
what it is not. \\
1.3. Internationally approved initiatives in Europe and Latin \\
America. \\
1.4. Objective view of CSR and subjective- corporate \\
reputation- of the phenomenon. Two sides of the same coin. \\
1.5. The need for CSR at current times. \\
1.6. The role of CSR in strategic management. \\
1.7. Corporate excellence, ethics in organizations and good \\
corporate citizenship. \\
1.8. Benefits at organizations that adopt responsible practices. \\
1.9. Corporate managerial responsibility, social responsibility \\
or organizational social responsibility. \\
1.10. Some evidences on CSR order: ethical code or good \\
practices, sectorial framework, international frameworks. \\
\hline Unit 2: Dimensions and interest groups in CSR \\
2.1 Economic Dimension \\
2.2 Social dimension \\
2.3 Environmental dimension \\
2.4 Stakeholders related with organizations \\
2.5 Maximization of the partner/ stockholder value vs. \\
Maximization of society's value. \\
\hline Unit 3: Tools for CSR management. \\
3.1. International initiatives on CSR. \\
3.2. Management models for internal stakeholders. \\
3.3. Management models for external stakeholders. \\
3.4. Complex perspective for managing stakeholders. \\
\hline Unit 4: Current tendencies on CSR \\
4.1. Alliances between business and NGO's \\
\hline .
\end{tabular}

Table 2. CSR Content at UCAN

\begin{tabular}{|l}
\hline \\
Unit 1. \\
1.1. Introduction \\
1.2. General overview
\end{tabular}

Unit 2.

2.1. Business and Society.

Unit 3.

3.1. CSR.

Unit 4.

4.1. CSR at Business schools

4.2. Ethics in business

Unit 5.

5.1. Personal Ethics.

5.2. Organizational Ethics.

5.3. Ethics and technology.

Unit 6.

6.1. Ethics in global business.

Unit 7.

7.1. Business and government.

7.2. Business ideology in Canada.

7.3. Consumers as stakeholders.

\section{Unit 8.}

8.1. Stakeholders and environment

8.2. Community as a stakeholder.

Unit 9.

9.1. -Owners as stakeholders.

9.2. Simulation of stakeholder's management.

Unit 10.

10.1. Globalization.

Unit 11.

11.1. Strategy and society.

\section{Unit 12.}

12.1. Socially responsible investment

12.2. Corporate Knights' Guide for Socially Responsible Investments.

Research work.

Investigate at the web sites of two organizations from a selected industry and set comparisons. In order to have a more complete vision on the industry, students will be able to analyze the websites of other organizations at the same industry. 
Table 3. Similarities and Differences in CSR Content between UMEX and UCAN

\begin{tabular}{|c|c|}
\hline SIMILARITIES & DIFFERENCES \\
\hline $\begin{array}{l}\text { Subjects } 1.1 \& 1.2 \text { at the UCAN, coincides with subjects } 1.1 \text {, } \\
1.2,1.41 .5 \& 1.9 \text {, at UMEX, since these topics are taught at } \\
\text { UCAN's course introduction and general overview. }\end{array}$ & $\begin{array}{l}\text { The UCAN does not consider a subject related to the - } \\
\text { Objective view of CSR and subjective- corporate reputation- } \\
\text { of the phenomenon, that is subject } 1.4 \text { at UMEX. Neither } \\
\text { it considers the difference between Corporate managerial } \\
\text { responsibility, social responsibility, and organizational social } \\
\text { responsibility, which is subject } 1.9 \text { at UMEX. }\end{array}$ \\
\hline \multicolumn{2}{|c|}{\begin{tabular}{ll|l} 
Subject 2.1 at the UCAN, coincides with subjects $2.1,2.2 \&$ & \\
2.5 at UMEX's program.
\end{tabular}} \\
\hline $\begin{array}{l}\text { Subjects } 3.2,3.3, \& 3.4, \text { at UMEX, coincide with subjects } \\
7.3,8.1,8.2,9.1, \& 9.2 \text { at the UCAN. }\end{array}$ & $\begin{array}{l}\text { UCAN's plan does not consider International initiatives on } \\
C S R \text {, which is subject } 3.1 \text { at UMEX. }\end{array}$ \\
\hline Subject 4.2 , at UCAN, coincides with subject 1.7, at UMEX & $\begin{array}{l}\text { The UCAN does not consider the subject Alliances between } \\
\text { business and NGO's, that is subject } 4.1 \text { at UMEX. } \\
\text { Neither considers specifically a subject referring to } \\
\text { Responsibility at small and medium size business, which is } \\
\text { subject } 4.2 \text { at UMEX. }\end{array}$ \\
\hline Subject 5.2, at UCAN coincides with subject 1.7, at UMEX. & $\begin{array}{l}\text { UMEX's plan does not consider the subjects Personal Ethics } \\
\text { and Ethics and technology, which are the subjects } 5.1 \text { and } 5.3 \\
\text { at the UCAN. }\end{array}$ \\
\hline No Similarities & $\begin{array}{l}\text { UMEX's plan does not consider Ethics in global business, } \\
\text { subject } 6.1 \text { at UCAN. }\end{array}$ \\
\hline $\begin{array}{l}\text { Subject } 7.3 \text { at the UCAN, coincides with } 2.4 \text {, at UMEX's } \\
\text { program. }\end{array}$ & $\begin{array}{l}\text { UMEX's plan does not include a topic on business ideology } \\
\text { in Mexico, equivalent to subject } 7.2 \text { Business ideology in } \\
\text { Canada, at the UCAN's plan. }\end{array}$ \\
\hline \multicolumn{2}{|l|}{$\begin{array}{l}\text { The two subjects at this unit, } 8.1 \& 8.2 \text {, at the UCAN, } \\
\text { coincide with subjects: } 2.3,2.4 \& 3.3 \text { at UMEX. }\end{array}$} \\
\hline \multirow{3}{*}{ Subject 9.1 at UCAN, coincides with $1.7 \& 1.9$, at UMEX. } & $\begin{array}{l}\text { UMEX's plan does not include Simulation of stakeholders' } \\
\text { management, subject } 9.2 \text { at the UCAN's plan. }\end{array}$ \\
\hline & $\begin{array}{l}\text { UMEX's plan does not include Socially responsible investment, } \\
\text { subject } 12.1 \text { at the UCAN. }\end{array}$ \\
\hline & $\begin{array}{l}\text { Neither includes a topic such as Corporate Knight's Guide for } \\
\text { Socially Responsible Investments, subject } \\
\text { 12.2, at UCAN. }\end{array}$ \\
\hline No Similarities & $\begin{array}{l}\text { UMEX's plan does not consider specifically a topic referring } \\
\text { to Globalization, as } 10.1 \text { of the UCAN's plan. }\end{array}$ \\
\hline \multicolumn{2}{|c|}{$\begin{array}{l}\text { Subject } 11.1 \text {, at the UCAN, coincides with } 1.6,2.2, \& 2.5 \text {, at } \\
\text { UMEX. }\end{array}$} \\
\hline Subject 12.1, at the UCAN, coincides with 2.5, at UMEX. & $\begin{array}{l}\text { UMEX's plan does not include a topic that proposes } \\
\text { a Socially responsible investment guide as subject } 12.2 \text { at the } \\
\text { UCAN. }\end{array}$ \\
\hline \multirow{2}{*}{$\begin{array}{l}\text { No Similarities } \\
\text { Although it is not specified at the UMEX's syllabus that } \\
\text { students must carry on a research, some academics interviews } \\
\text { declare that they actually ask students to conduct some } \\
\text { practical research. }\end{array}$} & \\
\hline & $\begin{array}{l}\text { UMEX's plan does not include a topic referring to a research } \\
\text { work as it is proposed the UCAN. }\end{array}$ \\
\hline
\end{tabular}

